\title{
1. Legal aspects of the protection of forest and marine biodiversity: understanding the context
}

Ed Couzens, Alexander Paterson and Sophie Riley

\section{INTRODUCTION}

As highlighted by its title, this book seeks to contribute to the global discourse on promoting the conservation and sustainable use of marine and forest biodiversity through legal responses at the international, regional and domestic levels. Its scope is accordingly somewhat broad, which brings to mind the words of Kenneth Noland, namely that 'for me context is the key - from that comes the understanding of everything'. Bearing this in mind, and not purporting to provide an understanding of everything, perhaps it would be prudent to use this chapter to set the necessary context to three broad issues. The first is the natural areas the book seeks to focus on - oceans and forests - with a view to highlighting their importance and the major threats posed to them. The second is the response of the international legal community pertaining to these areas, in an effort briefly to scope the international legal framework which informs, or should inform, the current and future effort of domestic law- and policy-makers to promote the conservation and sustainable use of marine and forest biodiversity. The third is a broad overview of the structure, form and content of the book.

1 Kenneth Noland, "CContext” Speech delivered at the University of Hartford (March, 1988)' - available at: http://www.sharecom.ca/noland/nolandtalk.html. 


\section{UNDERSTANDING THE NATURAL CONTEXT}

\subsection{The Importance of Oceans, and Threats to Them}

According to the website of the United Nations Sustainable Development Goals $^{2}$ oceans cover three-quarters of the surface of the earth, contain 97 per cent of the water on earth, and represent by volume 99 per cent of the living space of the earth. The oceans contain nearly 200,000 identified species, but actual numbers may well number in the millions. Oceans absorb about 30 per cent of carbon dioxide which humans produce, significantly mitigating the impacts of global warming. Oceans provide the world with its largest protein source, with more than 3 billion people depending on the oceans as their primary source of protein; more than 200 million people being employed, directly or indirectly, through marine fisheries; and more than 3 billion people depending on marine and coastal biodiversity to earn livelihoods. ${ }^{3}$

Numerous threats today endanger the health of the world's oceans. These include acidification of the oceans, which refers to ongoing shifts in acidity levels, which have numerous actual and potential future effects on corals, crustaceans, fish, marine mammals, molluscs, plankton, plants and many more species; increased incursions by invasive alien species, which provide one of the greatest current threats to biodiversity; increased coral bleaching, with it being probable that at least a quarter of the world's coral reefs have been irreparably damaged; and eutrophication, which entails the oversupply of nutrients, usually from fertilizer run-off, leading to excessive algal growth, which leads in turn to hypoxic (oxygen-starved) areas. Other threats include habitat destruction, with consequent negative impacts on biological diversity; increased human coastal development, with consequent polluting problems such as discharge, dumping, run-off, sediment deposits and sewage disposal that result from land-based human activities such as agriculture, construction, forestry, industry, land use, settlement and tourism. Melting of glacial and polar ice, and consequent sea level rise, are likely to have serious direct impacts on coastal dunes, coral reefs, fish stocks and human settlements, and also to have innumerable unforeseeable impacts. Rampant and chronic overfishing is one of the worst problems of all, but goes largely unacknowledged by nations, many of which fish in waters other than their own and provide huge subsidies to

2 UN SDGs, Goal 14: Conserve and sustainably use the oceans, seas and marine resources, (und.), available at: http://www.un.org/sustainabledevelopment/oceans/.

3 Ibid. 
keep the fishing effort afloat. Pollution is present and ever-increasing, in many forms, from raw sewage to plastic accumulation to heavy metals to acoustic pollution. Changes in overall ocean temperatures, which will have countless poorly understood impacts, are expected to exacerbate many of the problems already mentioned - and potentially even to alter thermohaline circulation, the patterns of movement of ocean currents which keep the oceans refreshed, renewed and prevent them from stagnating. ${ }^{4}$ Ultimately, of course, the problem is not that each one of these particular problems exists, but that they exist in conjunction with all of the others - it is the potential cumulative impact of all of these various problems that should terrify all of us. The impact of the combined whole may well prove to be greater by many orders of magnitude than can be understood from studying each problem separately.

\subsection{The Importance of Forests, and Threats to Them}

Forests cover 30 per cent of the earth's terrestrial landscape, ${ }^{5}$ and the importance and state of the world's forests have been canvassed in many international reports, including, recently, State of the World Forests (2016), ${ }^{6}$ Global Forest Resources Assessment $(2015)^{7}$ and Realizing Zero-Deforestation Transforming Supply Chains for the Future (2015). ${ }^{8}$ Cumulatively, these reports highlight the diverse benefits forests bring to the many species that inhabit, and indeed rely on, forest ecosystems, including the resources and ecosystem services they provide to the broader community. Forests are the largest repository of terrestrial biodiversity and home to many of the

4 There are many useful sources from which the general picture of the health of the oceans can be seen. One useful source, which identifies many of the problems, is the Outcomes Document 'The Future We Want' from the United Nations Conference on Sustainable Development (UNCSD), Rio de Janeiro, 20-22 June 2012. Another is Christian Nellemann, Stefan Hain and Jackie Alder (eds), In Dead Water: Merging of Climate Change with Pollution, Over-Harvest, and Infestations in the World's Fishing Grounds (UNEP, 2008) available at: http://old.unep-wcmc. org/medialibrary/2010/09/07/7e892368/InDeadWater.pdf.

5 United Nations Environmental Programme (UNEP), Keeping Track of Our Changing Environment: From Rio to Rio+20 (1992-2012) (2011) UNEP, Nairobi, 37; Food and Agriculture Organization (FAO), Global Forest Resources Assessment 2010 (2010) Forestry Paper No. 163, FAO, Rome, 10.

6 FAO, State of the World's Forests 2016: Forests and Agriculture: Land-Use Challenges and Opportunities (2016) Rome.

7 FAO, Global Forest Resources Assessment 2015: How Are the World's Forests Changing (2016) second edition, Rome.

8 Carbon Disclosure Project, Realizing Zero-Deforestation: Transforming Supply Chains for the Future (2015) CDP Report. 
world's most endangered species. ${ }^{9}$ Furthermore, they provide numerous environmental goods and services to people living within, adjacent to, or even at a significant distance from the forested areas. Forests filter the earth's polluted air, mitigate the impacts of climate change, improve the quality and quantity of essential fresh water resources, preserve and replenish soil stocks, and provide food for nourishment, wood energy for cooking and warmth, and construction materials for shelter.

Notwithstanding their importance, forests are under significant threat from agriculture, urban expansion, infrastructure development and mining activities. Global forest cover has reduced by 129 million hectares since $1990,{ }^{10}$ and while the rate of deforestation has slowed, the global net rate of deforestation remains at approximately 3.3 million hectares per annum. ${ }^{11}$ Adopting a slightly longer temporal perspective, the earth has lost approximately 40 per cent of global forest cover in the last 300 years. ${ }^{12}$ While there are naturally significant regional variations, deforestation is now most prevalent in the tropical climatic domain and in low-income group countries. ${ }^{13}$ In these regions, the contribution of different activities to deforestation is as follows: large-scale commercial agriculture (40 per cent); local subsistence agriculture (33 per cent); infrastructure development (10 per cent); and mining (9 per cent). ${ }^{14}$

This rapid rate of deforestation, coupled with degradation of the remaining forested areas, significantly undermines the provision of the numerous essential environmental goods and services forests afford to humans and other species inhabiting the earth. Focusing, for example, on climate change, deforestation is the third-largest source of greenhouse gas emissions, contributing approximately 19 per cent to global emissions. ${ }^{15}$ A failure to curb deforestation and associated forest degradation is recognized as significantly jeopardizing any global effort to reduce global warming. ${ }^{16}$

9 FAO, State of the World's Forests - Enhancing the Socio-Economic Benefits from Forests (2014) FAO, Rome, vii; and FAO, Global Forest Resources Assessment 2010 (2010) Forestry Paper No. 163, FAO, Rome, 49-64.

10 FAO, Global Forest Resources Assessment 2015: How Are the World's Forests Changing (2016) second edition, Rome, 3.

11 Ibid.

12 The Economics of Ecosystems \& Biodiversity: An Interim Report (2008), European Communities, 12; UNEP Annual Report 2010 (2011) UNON, Nairobi, 15.

13 FAO, State of the World's Forests 2016: Forests and Agriculture: Land-Use Challenges and Opportunities (2016), Rome, 7-23.

14 Ibid.

15 WWF, Deforestation \& Climate Change (2007), 2.

16 WWF, Climate Solutions (2007) 20; WWF, Deforestation \& Climate Change (2007) 4. 
Conserving and providing for the sustainable use of the world's forests is clearly a global imperative. However, given the myriad threats to forests and the resources inherent in them, and the numerous sectors holding vested interests in their conservation, rehabilitation and use, forging global, regional and domestic legal frameworks to do so has proven a challenging enterprise.

\section{UNDERSTANDING THE INTERNATIONAL LEGAL CONTEXT}

\subsection{International Law and the Oceans}

According to Dugard, 'the evolution of the law of the sea is the history of international law itself, for since its earliest days international law has been deeply involved in the regulation of navigation and fishing. ${ }^{17}$

Moreover, international oceans governance has been described as a 'vast, complex and highly technical sub-discipline of international law' with its 'environmental regime consist[ing] of overarching or framework measures, issue-specific measures, regional measures; and various institutions, mechanisms and procedures; all aimed at regulating deleterious effects of human activities on the marine environment'. ${ }^{18}$ Arguably, however, there have been four major instruments which have driven legal governance of the oceans more than have any others.

First, in the case of international governance of the oceans, there is a single document to which much can be traced - and where many of the current problems faced by the oceans can be seen to have received their first philosophical grounding. In 1609 the Dutch jurist Huig de Groot ('Grotius') published a pamphlet entitled Mare Liberum (the 'Freedom of the Seas'). ${ }^{19}$ The pamphlet was written on behalf of the Dutch East India Company and was designed to promote the idea that the oceans were open to all for free trade and free use. The Mare Liberum was written to refute

17 John Dugard, International Law: A South African Perspective (3rd edn, Juta, 2005) 354; quoted in Louis Kotzé, 'Fragmentation of International Environmental Law: An Oceans Governance Case Study' in: Ed Couzens and Tuula Honkonen (eds), International Environmental Law-making and Diplomacy Review 2008 (University of Joensuu/UNEP Course Series 8, 2009) 11.

18 Kotzé, ibid n 17, 13-14.

19 Huig de Groot, The Freedom of the Seas, or the Right Which Belongs to the Dutch to Take Part in the East Indian Trade (trans. Ralph Van Deman Magoffin, Oxford University Press, 1916). 
the 'unjustified' claims of Spain and Portugal to a right to exclude foreigners from the high seas. According to Grotius, this is:

. . . a new case. It is in very truth no petty case such as private citizens are wont to bring against their neighbors about dripping eaves or party walls; nor is it a case such as nations frequently bring against one another about boundary lines or the possession of a river or an island. No! It is a case which concerns practically the entire expanse of the high seas, the right of navigation, the freedom of trade!! Between us and the Spaniards the following points are in dispute: Can the vast, the boundless sea be the appanage of one kingdom alone, and it not the greatest? Can any one nation have the right to prevent other nations which so desire, from selling to one another, from bartering with one another, actually from communicating with one another? Can any nation give away what it never owned, or discover what already belonged to someone else? Does a manifest injustice of long standing create a specific right? ${ }^{20}$

According to Grotius, further:

The question at issue then is not one that concerns an INNER SEA, one which is surrounded on all sides by the land and at some places does not even exceed a river in breadth, although it is well known that the Roman jurists cited such an inner sea in their famous opinions condemning private avarice. No! the question at issue is the OUTER SEA, the OCEAN, that expanse of water which antiquity describes as the immense, the infinite, bounded only by the heavens, parent of all things; the ocean which the ancients believed was perpetually supplied with water not only by fountains, rivers, and seas, but by the clouds, and by the very stars of heaven themselves; the ocean which, although surrounding this earth, the home of the human race, with the ebb and flow of its tides, can be neither seized nor inclosed; nay, which rather possesses the earth than is by it possessed. ${ }^{21}$

This latter quotation, particularly in the lines beginning from 'that expanse of water', is arguably the single most famous - and also arguably the most influential - quotation on the legal nature of the world's oceans. The pamphlet is considered, arguably unfortunately, to have set the tone for four centuries of states (and related entities) claiming uninhibited access to the oceans - and to the resources of the oceans.

Grotius' views were strongly entrenched by the second major development - an important early arbitral ruling, that of the Bering Sea Fur Seals Arbitration. ${ }^{22}$ This arbitration concerned a right claimed by the United States to arrest Canadian ships on the high seas in order to protect fur

\footnotetext{
20 Ibid. Preamble, 3.

$21 \quad$ Ibid, ch. 5, 37.

22 Bering Sea Fur Seal Arbitration (Great Britain v USA), Moore's International Arbitration Awards (1898) 755.
} 
seals in a situation where these marine mammals returned cyclically from the high seas to US territory, a right which was disputed (on behalf of Canada) by Great Britain. The arbitral tribunal found against the US arguments and held that the doctrine of freedom of the high seas was to prevail. Birnie and Boyle have described the arbitral decision in the following terms:

[t]he importance of this decision to the development of the law concerning conservation of marine living resources cannot be overstressed. It laid the twin foundations for subsequent developments over the next century. First, it confirmed that the law was based on high seas freedom of fishing and that no distinction was to be made in this respect between fisheries and marine mammals . . secondly, it recognized the need for conservation to prevent overexploitation and decline of a hunted species, but because of the former finding, it made this dependent on the express acceptance of regulation by participants in the fishery. ${ }^{23}$

Sands has even gone so far as to explain that the modern rules of international environmental law can be traced back 'to the late nineteenth century, and an obscure spat between the United States and Britain' with the 'world's first reported environmental dispute concerning the littleknown fur seals'. 24

While Grotius' argument concerned rights of navigation, and the arbitral decision concerned the issues of fisheries and hunting of marine mammals, the consequences of both have extended further than merely these issues. The damage that has been done to the biological diversity of the oceans in the four centuries since 1609 is incalculable, but has only in recent years truly begun to be understood. At the same time the extent of the damage done is becoming obvious, indicating that Grotius' concept of freedom of the seas is attractive only at a superficial, and political, level. In addition, lack of effective governance over the world's oceans has left them with very little protection from abuse.

The third significant development was the proclamation in 1945 by President Truman of the United States of a Policy with Respect to Coastal Fisheries in Certain Areas of the High Seas. ${ }^{25}$ In the preamble to this document, Truman indicated that:

23 Patricia Birnie and Alan Boyle, International Law and the Environment (2nd edn, Oxford University Press, 2002) 649-650.

24 Philippe Sands, Lawless World: Making and Breaking Global Rules (Penguin, 2006) 71-74.

25 Harry S. Truman, Presidential Proclamation No. 2668 - 'Policy of the United States with Respect to Coastal Fisheries in Certain Areas of the High Seas', 
[w] hereas for some years the Government of the United States of America has viewed with concern the inadequacy of present arrangements for the protection and perpetuation of the fishery resources contiguous to its coasts, and in view of the potentially disturbing effect of this situation, has carefully studied the possibility of improving the jurisdictional basis for conservation measures and international cooperation in this field; and

$\cdots$

Whereas the progressive development of new methods and techniques contributes to intensified fishing over wide sea areas and in certain cases seriously threatens fisheries with depletion; and

Whereas there is an urgent need to protect coastal fishery resources from destructive exploitation, having due regard to conditions peculiar to each region and situation and to the special rights and equities of the coastal State and of any other State which may have established a legitimate interest therein; ${ }^{26}$

\section{Truman then proclaimed that:}

the United States regards it as proper to establish conservation zones in those areas of the high seas contiguous to the coasts of the United States wherein fishing activities have been or in the future may be developed and maintained on a substantial scale. Where such activities have been or shall hereafter be developed and maintained by its nationals alone, the United States regards it as proper to establish explicitly bounded conservation zones in which fishing activities shall be subject to the regulation and control of the United States. Where such activities have been or shall hereafter be legitimately developed and maintained jointly by nationals of the United States and nationals of other States, explicitly bounded conservation zones may be established under agreements between the United States and such other States; and all fishing activities in such zones shall be subject to regulation and control as provided in such agreements. The right of any State to establish conservation zones off its shores in accordance with the above principles is conceded, provided that corresponding recognition is given to any fishing interests of nationals of the United States which may exist in such areas. The character as high seas of the areas in which such conservation zones are established and the right to their free and unimpeded navigation are in no way thus affected. ${ }^{27}$

This proclamation has been described by the United Nations Division for Ocean Affairs and the Law of the Sea as having been 'the first major

Basic Document No. 6, September 28, 1945; Online by Gerhard Peters and John Woolley, The American Presidency Project, available at: http://www.presidency. ucsb.edu/ws/?pid $=58816$.
26 Ibid.
27 Ibid. 
challenge to the freedom of the seas doctrine'. ${ }^{28}$ The claim set in motion a cascade of claims by other states: Argentina in 1946, Chile and Peru in 1947 and Ecuador in 1950 all claimed 200-mile zones; after the Second World War, Egypt, Ethiopia, Libya, Saudi Arabia, Venezuela and some Eastern European countries claimed 12-mile territorial seas, departing from the traditional three-mile limit. Later on, Indonesia claimed a right to dominion over the waters between its 13,000 islands; and the Philippines made a similar claim. In 1970, Canada claimed a right to regulate navigation for 100 miles from its shores. ${ }^{29}$ Clearly, the Grotian doctrine of freedom of the seas was facing challenges.

In November 1967 the Ambassador to the United Nations for Malta, Arvid Pardo, made a famous speech in which he claimed that the then rivalry between the 'super powers' of the Soviet Union and the United States was spreading to the oceans, that the oceans were being poisoned by pollution, and that conflicting legal claims were making governance difficult. He then called for 'an effective international regime over the seabed and the ocean floor beyond a clearly defined national jurisdiction' - describing this as the 'only alternative by which we can hope to avoid the escalating tension that will be evident if the present situation is allowed to continue'. ${ }^{30}$ This led to the fourth major development: the opening in 1973 of negotiations towards a new Convention on the Law of the Sea, which negotiation would conclude with the adoption in 1982 of the United Nations Convention on the Law of the Sea (UNCLOS) $)^{31}$ - an extremely ambitious effort to codify as much customary law as possible relating to the use of the oceans. UNCLOS provides regulatory measures, or at least principles to guide the regulation of issues ranging from navigational rights through natural resource use and scientific research to the settlement of disputes.

The settling of maritime zones by UNCLOS, largely recognized by every state including those (such as the United States) which have not ratified UNCLOS, is extremely important as many management and protective consequences flow from this. The certainty provided by the entrenching of these zones is an important and positive step towards greater protection of the oceans.

28 Division for Ocean Affairs and the Law of the Sea, 'A Historical Perspective', 1998, available at: http://www.un.org/depts/los/convention_agreements/convention_ historical_perspective.htm.

29 Ibid.

30 'Third United Nations Conference on the Law of the Sea'. Ibid.

31 United Nations Convention on the Law of the Sea (UNCLOS), Montego Bay, 10 December 1982, in force 16 November 1994, 21 International Legal Materials (1982) 1261. 
On the other hand, UNCLOS is proving sadly deficient as a protective tool. UNCLOS does provide that:

[n]ecessary measures shall be taken in accordance with this Convention with respect to activities in the $\mathrm{Area}^{32}$ to ensure effective protection for the marine environment from harmful effects which may arise from such activities. ${ }^{33}$

Unfortunately, despite provisions like this, many of UNCLOS' provisions can be said even to work against environmental protection. Consider, for instance, the provision that: '[t]he coastal State shall determine its capacity to harvest the living resources of the exclusive economic zone'; but that '[w] here the coastal State does not have the capacity to harvest the entire allowable catch, it shall, ... give other States access to the surplus of the allowable catch, ...' ${ }^{34}$ This provision makes it difficult for states to justify protective, even conservationist, measures, and gives other states at least a measure of justification for their vessels intruding into the waters of other states, where those states do not have effective means to police their zones.

While UNCLOS is the centrepiece, there really are two noticeable features about the oceans governance regime that need to be highlighted. These are, first, that the oceans do not lack for governance with a plethora of global and regional, multilateral and bilateral, instruments in place; and, second, that, apart from a few specific success stories such as the creation of certain marine protected areas, overall this cornucopia of international legal instruments is not, unfortunately, doing a great deal to solve oceans-related problems.

The University of Oregon's International Environmental Agreements Database Project ${ }^{35}$ lists 349 'instruments' (Agreements and/or Amendments, and including Declarations and Protocols) of global scope under the subject heading 'Ocean' and 260 such regional instruments. In respect of 'fish' alone, there are 197 global instruments listed; in respect of 'marine pollution' there are 148. Leaving aside the argument that there is merit to be found in focused regional and/or issue-specific governance, this proliferation of international instruments implies a high degree of 'fragmentation' in the area. While there may be some benefits which accrue from this, such as increased and positive specialization, there are many problems which arise - such as contradictory legal instruments,

32 The 'Area' being defined, in Art. 1, as 'the seabed and ocean floor and subsoil thereof, beyond the limits of national jurisdiction'.

33 Art. 145: 'Protection of the Marine Environment'.

34 Art. 62: 'Utilization of the Living Resources'.

35 See https://iea.uoregon.edu/. 
conflict between regulatory bodies, overlapping of provisions, duplication and doubling of efforts, and general diminished efficiency levels. ${ }^{36}$

There are specific global and regional conventions which provide for conservation, management and protection measures, such as conventions which deal with matters as disparate as anti-fouling compounds, ballast water disposal, collision prevention, container safety, dumping of wastes, undersea heritage protection, maritime claims, navigational aids, safety of life at sea, search and rescue, and many, many more. These tend to focus on aspects of environmental protection, or on issues which might by implication cover environmental protection, rather than providing general environmental protection. This profusion may itself be a problem for effective governance.

Birnie, Boyle and Redgwell do indicate that, in their opinion, 'there is evidence that international regulation of serious environmental risks has proved more successful with regard to ships than for other comparably hazardous undertakings'; ${ }^{37}$ but it is telling that this faint praise is the best that they seem to be able to offer. In the face of the numerous threats to the oceans, effective oceans governance seems to be floundering between the Scylla of state sovereignty and firm belief in the nature of the oceans as 'common to all' and 'free for the taking', and the Charybdis of uncoordinated, overly profuse and insufficiently enforced international law..$^{38} \mathrm{It}$ is in this context that increased understanding of multilateral environmental agreements related to oceans governance, and of the strengths and weaknesses which these agreements evidence, is urgently needed.

At time of writing, we were on the cusp of an exciting development potentially even of such importance as to be a fifth seminal development. On 19 June 2015 the UN General Assembly (UNGA) agreed ${ }^{39}$ that it would begin the process of developing an international legally binding instrument, under the UNCLOS, on the 'conservation and sustainable use of marine biological diversity of areas beyond national jurisdiction' ${ }^{40}$ The UNGA decided to establish, before holding an intergovernmental conference, a Preparatory Committee, which would make substantive recommendations to the UNGA on the possible elements of a draft text,

\footnotetext{
36 See, generally, Kotzé, supra $n 17$.

37 Patricia Birnie, Alan Boyle and Catherine Redgwell, International Law and the Environment (3rd edn, Oxford University Press, 2009) 441.

38 Ed Couzens, Tuula Honkonen and Melissa Lewis, 'Editorial Preface' in Ed Couzens, Tuula Honkonen and Melissa Lewis (eds), International Environmental Law-making and Diplomacy Review 2012 (University of Eastern Finland/UNEP Course Series 12, 2013) xi.

39 Resolution 69/292.

40 See, generally, http://www.un.org/depts/los/biodiversity/prepcom.htm.
} 
taking into account reports from the Co-Chairs of the Ad Hoc Openended Informal Working Group to study issues relating to conservation and sustainable use of marine biological diversity in areas beyond national jurisdiction. ${ }^{41}$ The Prep Comm met in March and April 2016, in August and September 2016, and at time of concluding the manuscript of this present book (in March 2017) was about to begin its third meeting.

The Prep Comm is to report to the UNGA, by the end of 2017, on the progress of negotiations; and the most recent development was the release by the Chair of a non-paper on the elements of a draft text. ${ }^{42}$ At present the text appears to be taking shape under the six headings of 'General principles and approaches', 'International cooperation', 'Marine genetic resources, including questions on the sharing of benefits', 'Measures such as area-based management tools, including marine protected areas', 'Environmental impact assessments', and 'Capacity building and transfer of marine technology' - all of which have been the focal areas of different Working Groups. ${ }^{43}$

\subsection{International Law and Forests}

Standing in stark contrast to the highly regimented ocean governance regime, efforts to forge a dedicated, binding international legal instrument to protect forest biodiversity have proven far less 'energetic'. Initiatives aimed at fashioning an international forest convention, preceding and during the United Nations Conference on the Environment and Development held in Rio in 1992, proved largely fruitless and resulted in the adoption of the Non-Legally Binding Authoritative Statement of Principles for a Global Consensus on Management, Conservation and Sustainable Development of All Types of Forests ${ }^{44}$ (Forest Principles) and a rather bland commitment in Agenda 21 to 'facilitate and support the effective implementation' of the 1992 Forest Principles and 'consider the need for and the feasibility of all kinds of appropriate internationally agreed arrangements to promote international cooperation on forest management, conservation and sustainable development of all types of forests'. ${ }^{45}$

41 Ibid

42 'Chair's non-paper on elements of a draft text of an international legallybinding instrument under the United Nations Convention on the Law of the Sea on the conservation and sustainable use of marine biological diversity of areas beyond national jurisdiction', 28 February 2017, http://www.un.org/depts/los/biod iversity/prepcom_files/Chair_non_paper.pdf.

43 Ibid.

4431 ILM 881 (1992).

45 Agenda 21, para 11.12(e). 
The form and content of the 1992 Forest Principles have been criticized by several commentators as 'juridically lame', ${ }^{46}$ 'poorly drafted' and 'of little assistance'. ${ }^{47}$ The Forest Principles have subsequently been complemented by the Non-Legally Binding Instrument on All Types of Forests, ${ }^{48}$ adopted by the UNGA in 2007, which prescribe four global objectives on forests and encourage all states to progress towards their achievement by 2015 . These objectives are to: reverse the loss of forest cover through sustainable forest management; enhance forest-based economic, social and environmental benefits; significantly increase the area of protected forests; and reverse the decline in official development assistance for sustainable forest management. ${ }^{49}$ Recognized as providing a 'more clearly drafted reflection of the evolution of an international response' to promoting sustainable forest management, ${ }^{50}$ the 2007 Non-Legally Binding Instrument, as its name indicates, is unfortunately non-binding, and the challenges associated with its weak international status are clearly reflected in the Outcomes Document of the United Nations Conference on Sustainable Development, 2012 (UNCSD, or 'Rio+20'), 'The Future We Want', which called for 'increased efforts to strengthen forest governance frameworks' and the 'urgent implementation' of the objectives set out in the 2007 Non-Legally Binding Instrument. ${ }^{51}$

The failure to forge a dedicated binding international forestry instrument does not appear to be linked to the absence of relevant international fora tasked with promoting the management, conservation and sustainable development of all types of forests and to strengthen long-term commitment towards achieving this end, which would naturally include the conclusion of relevant binding international instruments. These international fora include, in chronological order, the Intergovernmental Panel on Forests (1995-1997), the International Forum on Forests (1997-2000), the International Arrangement of Forests (2000-present), the United Nations Forum on Forests (2000-present), and the Collaborative Partnership on Forests (2001-present). ${ }^{52}$ The failure has been attributed by several

\footnotetext{
46 Barbara Ruis, 'No Forest Convention but Ten Tree Treaties' (2001) 52(3) Unasyla (available at www.fao.org/docrep/003/y1237e/y1237e03.htm).

47 Philippe Sands and Jacqueline Peel, Principles of International Law (3rd edn, Cambridge University Press, 2012) 497.

48 UNGA Res A/Res/62/98 (31 January 2008).

49 Ibid, para IV(5).

50 Sands and Peel, supra n 47, 499.

51 'The Future We Want', UNGA Res A/66/288 (11 September 2012) paras 193-194.

52 For a brief description of these international fora, see: Sands and Peel, supra n 47, 497.
} 
commentators predominantly to sensitivity regarding national sovereignty over forest resources, an issue which will no doubt continue to plague future efforts to forge such an instrument. ${ }^{53}$

The absence of a dedicated and binding international forestry instrument does not, however, mean that forests fall entirely outside the remit of international environmental instruments and arrangements. Several international and regional environmental conventions seek to regulate activities related to forests. ${ }^{54}$ These include the Convention on Biological Diversity; ${ }^{55}$ the United Nations Convention on Climate Change ${ }^{56}$ (read together with the Kyoto Protocol ${ }^{57}$ and the Paris Agreement ${ }^{58}$ ); the United Nations Convention to Combat Desertification in those Countries Experiencing Serious Drought and/ or Desertification, particularly in Africa; ${ }^{59}$ the Ramsar Convention on Wetlands of International Importance Especially as Waterfowl Habitat; ${ }^{60}$ the Convention Concerning the Protection of the World Cultural and Natural Heritage, ${ }^{61}$ and the Convention on International Trade in Endangered Species of Wild Fauna and Flora. ${ }^{62}$ These are complemented by several trade instruments, most notably the International Tropical Timber Agreement (2006), ${ }^{63}$ developed under the auspices of the International Tropical Timber Organization, and the European Union's Forest Law Enforcement, Governance and Trade (FLEGT) Scheme. ${ }^{64}$ While primarily focusing on promoting international trade in timber, they do seek simultaneously to promote sustainable forest management and the legal harvesting of timber. Finally, several international forest certification schemes, most notably the Forest Stewardship Council ${ }^{65}$ and the Programme for the Endorsement of Forest Certification, ${ }^{66}$ also

3 Birnie, Boyle and Redgwell, supra n 37, 695.

See, generally, Ruis, supra $\mathrm{n} 46$.

(1992) 31 ILM 818.

(1992) 31 ILM 849.

(1998) 37 ILM 22.

United Nations FCCC/CP/2015/10/Add.1.

(1994) 33 ILM 1328.

(1983) 22 ILM 698.

(1972) 11 ILM 1358

(1973) 12 ILM 1085.

63 UN TD/TIMBER.3/12 (1 February 2006). The Agreement, which entered into force on 7 December 2011, replaced the 1994 International Tropical Timber Agreement ((1994) 33 ILM 1014).

64 See generally: http://www.euflegt.efi.int/about-flegt.

65 See generally: https://ic.fsc.org/en.

66 See generally: http://www.pefc.org/. 
seek to promote sustainable forestry management. Commentators are, however, quick to highlight the problems inherent in relying on such instruments and arrangements in the absence of a global specific binding forestry instrument. ${ }^{67}$ First, notwithstanding the diversity of international instruments and arrangements, several overlaps and gaps exist in their coverage in so far as they relate to forests. ${ }^{68}$ Second, the fragmented current array of instruments is unable to address the 'multi-functionality of forests and related resources' in a coherent and coordinated manner. ${ }^{69}$ Third, while simultaneously promoting sustainable forest management, the trade instruments are 'still effectively little more than a commoditymarket adjustment among consumer and producer states' ${ }^{70}$ Fourth, concerns have been raised about the merits of devolving global forest governance to forest certification schemes as opposed to regulation through a global forest convention. ${ }^{71}$

In the current vacuum, international and domestic policy-makers continue to grapple with forging workable law and policy responses simultaneously to conserve forests and provide for their sustainable use. Domestically, at last count, some 156 countries had adopted specific forestry legislation, ${ }^{72}$ but this legislation naturally requires constant amendment to improve its formulation and deal with emerging issues. In the absence of a holistic international binding forestry instrument, this process currently involves cobbling together elements from a diverse range of international and regional substantive contexts. This is not an ideal situation, especially taking into account the central focus placed on forests in the Sustainable Development Goals (SDGs) set out in Transforming our World: the 2013 Agenda for Sustainable Development. ${ }^{73}$

67 See generally: Anja Eikermann, Forests in International Law: Is There Really a Need for an International Convention? (Springer, 2015); Rowena Maguire, Global Forest Governance: Legal Concepts and Policy Trends (Edward Elgar, 2013); and Richard Tarasofsky, Assessing the International Forest Regime (IUCN, 1999).

68 Ruis, supra n 46.

69 Eikermann, supra n 67, 185.

70 Birnie, Boyle and Redgwell, supra n 37, 694.

71 Steven Bernstein and Benjamin Cashore, 'Non-State Global Governance: Is Forest Certification a Legitimate Alternative to a Global Forest Convention' in Steven Bernstein and Benjamin Cashore, Hard Choices, Soft Law: Combining Trade, Environment, and Social Cohesion in Global Governance (Ashgate Press, 2004) 33-63.

72 FAO, Global Forest Resources Assessment 2010 (2010) Forestry Paper No. 163, FAO, Rome, 149-162.

73 UN, Transforming Our World: 2030 Agenda for Sustainable Development (2015) UNGA Res. 70/1 (2015). See specifically SDG 2, 6 and 15. 


\section{INTRODUCING THE BOOK'S SCOPE, STRUCTURE AND CONTENT}

The breadth of issues embedded within the two broad themes of forest and marine biodiversity is striking. Topics include the following: tropical forest biodiversity; endangered forest species; human and wildlife conflict; forest conservation; climate change and forest management; sustainable forests; forest environments and water protection; coastal marine biodiversity; local wisdom, shifting cultivation and forest policy; protection of river biodiversity; wetlands, peat lands and mangroves; biodiversity, food security, and livelihoods; enforcement and compliance issues in forest law; promoting forest connectivity; forests and ecosystem services; forest products trade and sustainability.

In an effort to create a coherent structure for the collection of chapters contained in this book, three main divisions were created. Part 2 of the book contains chapters dealing with global issues of relevance to the protection of biological diversity generally. Part 3 contains chapters dealing with the protection of biological diversity in forests. Part 4 contains chapters grappling with the protection of biological diversity in marine areas.

\subsection{Global Issues of Protection of Biological Diversity}

The approach taken in this part of the book 'sets the scene' for similar identification of problems and 'remedying thereof' for many other issueareas in the later chapters.

The first of the four chapters in this section is by Gay Morgan: 'Moral Boundaries, Anthropocentrism and Biodiversity: Possums in New Zealand as an Example'. Morgan's chapter takes a jurisprudential/philosophical look at why biological diversity should be protected through a consideration of how different 'interest groups' (Biospheres; Threatened Species; Individual Members of Threatened Species; the Earth itself; and Humanity) might value biodiversity. In particular, the chapter canvasses the 'moral considerateness' of species labelled as 'pests', and whether such a classification automatically leads to such species losing their status as morally considerate beings. Morgan argues that moral considerateness imposes limitations on how society regulates all species, including unwanted ones. There is then consideration of how different interests might be reconciled through the medium of justice in a national legal system - the particular case of New Zealand is used as an example.

The second chapter in this section is by Nicholas Robinson: 'For Peat's Sake: Environmental Law Amidst the Bogs'. As with Morgan's chapter, this is a rather unusual contribution, as it raises and then deals extensively 
with a problem which has been virtually unconsidered worldwide. The issue raised by Robinson is that of the danger to, and the need for protection of, peat - which is not quite a 'forest' issue (nor a marine issue) but is close enough to be justifiably included with its links to wetland protection and to REDD+ initiatives. Robinson grapples with the vexed issue of preserving the earth's peat reserves, which, he argues, is central to any successful global efforts to cap the rise in earth's temperatures to 2 degrees Celsius. He begins by outlining the nature, importance and threats posed to peat stocks, highlighting that there are available alternatives for virtually every use of peat, there is no way effectively to use peat 'sustainably', and that remaining peat should accordingly be preserved in parks or other protected areas, and left intact underground, wherever it is already buried or will be covered with coastal waters as sea levels rise. He then proceeds to survey the historic role of law in preserving peat and concludes that environmental law still largely ignores peat. This leads him to conclude that there are compelling arguments for environmental policy-makers to take a fresh look at peat and forge workable legal frameworks to preserve it. With a view to providing necessary future guidance to policy-makers in this regard, the author traverses the international legal frameworks of relevance to peat, distils key legal principles underlining any future legal framework governing peat, and finally through a case study of Indonesia, distils a set of elements that should be considered in drafting new peat legislation, whether by local, national or regional authorities. The experiences of numerous countries are considered, with some intensive case studies being offered. Issues of financing and international cooperation are considered before suggestions are made as to how appropriate national legislation might be framed.

Forests and the marine environment are home to numerous endangered species of wild fauna and flora. The third and final chapter in this part is by Lin Heng Lye and Sallie Chia-Wei Yang: 'Illegal Trade in Endangered Forest and Marine Species - Enhancing Laws and Enforcement: a SouthEast Asian Perspective'. The authors focus specifically on one legal response to dealing with conserving these species, namely regulating the international trade in endangered species. This chapter considers illegal international trade in wild animal species, and the devastating effects of this on biological diversity. The chapter considers (in fact, re-examines) the Convention on International Trade in Endangered Species of Wild Fauna and Flora, 1973 (CITES) and its implementation, with particular focus on South-East Asia and its regional centre for combating wildlife trade, the ASEAN Wildlife Enforcement Network (ASEAN-WEN). It calls for recognition of illegal wildlife trade as a transnational environmental crime, and examines the UN Convention against Transnational Organized 
Crime, 2003 (UNTOC); the UN Convention against Corruption, 2003 (UNCAC); the ASEAN Mutual Legal Assistance Treaty on Criminal Matters, 2004 (MLAT); International Standards on Combating Money Laundering and the Financing of Terrorism and Proliferation, 2012 (FATF); and the London Declaration on Wildlife Trade, 2014. The chapter makes recommendations for more effective policing and enforcement in the context of ASEAN and East Asia and the editors placed it under the heading of 'global issues' as it deals with regional international cooperation, rather than directly with national initiatives.

\subsection{The Protection of Biological Diversity in the Forest Environment}

As has been highlighted previously in this introduction, agricultural production (and associated deforestation) and biodiversity conservation often significantly conflict with one another. One approach to emerge in the past two decades to reconcile these two activities is agroforestry. The first chapter in this part of the book is by Marcia Fajardo Cavalcanti de Albuquerque: 'Biodiversity and Agriculture - Friends or Foes? The Legal Implementation of Agroforestry Practices in Brazil'. This chapter considers the uneasy relationship between the protection of biological diversity and the promotion of agriculture. The history of agriculture in Brazil is considered, with problems that have been caused by agriculture. Legislative control has increased but has not proved adequate, and biodiversity has continued to decline. The thrust of the chapter is to suggest ways in which a new approach could be taken - an integrated management approach that introduces the concept of 'agroforestry' and balances biodiversity protection with agricultural practices. The author seeks to demonstrate that agricultural production and biodiversity conservation can be allies through the adoption of agroforestry practices. She commences by first considering the form, nature and importance of agroforestry, the recognition accorded to it in key international conventions, and elements found in legal and policy frameworks providing for its effective domestic implementation. Having provided this context, she then critically evaluates the Brazilian legal framework with a view to determining whether it provides a workable regime for promoting agroforestry.

The second chapter in this part is by Bingyu Liu: 'Forest Biodiversity Conservation: Strengthening the Regulation and Management of Chinese Enterprises during Foreign Investment'. This chapter considers the relatively recent, but large-scale, expansion of investment into foreign, especially developing, countries by China. This expansion (if not controlled and sustainably managed) has implications, potentially negative, for the conservation of forest biodiversity. Suggestions are made as to how such 
investment initiatives might be sustainably managed through requirements that environmental consideration be made a compulsory part of the investment process - and through the strengthening of corporate social responsibility and the adoption of socially (and environmentally) responsible business practices.

The third chapter in this part is by Yilin Pei: 'Addressing Human and Wildlife Conflict in Forest Protected Areas: A Critical Analysis of China's Nature Reserve Management Experience'. This chapter concerns the relationship/s between local communities and nature and forest reserves and how the interests of both can be taken into account in sustainable management and protection of biological diversity. The general history of the creation and protection of forest reserves in China is canvassed. Forest reserves face many of the problems faced by forest reserves worldwide, such as illegal logging, ongoing pressure to open them for resource use, and resentment from local communities. Different management options, and different legislative and funding options, are explored for possible reform.

The final chapter in this part is by Amber Prasad Pant: 'Climate Change and Forest Management in Nepal'. The chapter analyses recent policies and legal frameworks dealing with climate change and sustainable forest management and draws the conclusion that climate change is increasing at global, regional and national level. The health and vitality of forest ecosystems are adversely affected by climatic as well as land use changes. The role of forest management, and the legal control thereof, in adapting to and mitigating the impact of climate change has become a global concern. Nepal has a climate change policy and has taken various legislative steps. While Nepal's own greenhouse gas emissions are negligible, the country faces significant problems with the effects on its forests from emissions from developed countries and its large neighbours China and India.

\subsection{The Protection of Biological Diversity in the Marine Environment}

The first chapter in this part is by Violeta S. Radovich: 'Governance of Oil and Gas Exploration and Exploitation at Sea: Towards Coastal Marine Biodiversity Preservation'. This chapter considers the adverse effects on marine biodiversity from the exploration for, and exploitation of, oil and gas in the marine environment. It is argued that if appropriate environmental law tools are not applied at appropriate stages, then environmental damage will likely ensue, raising issues of liability and reparation for environmental damage. Currently, there is no convention or fund related to civil liability arising from pollution by offshore oil and gas exploration and exploitation. The chapter canvasses the history of the development of 
draft international legal regimes - and the adoption of various relevant, but non-specific international legal instruments. In the conclusion the argument is made that the development of a new convention to deal specifically with the exploration for, and exploitation of, marine oil and gas would be valuable.

The second chapter in this part is by Anastasia Telesetsky: 'The Valuable Role that Private Environmental Governance Might Play in Managing Global Fisheries Resources'. This chapter explains that international governance of highly migratory fish species, such as sharks, billfish and tuna, has proved largely ineffective - for various reasons. Against the backdrop of such failure, it is argued that a valuable role could be played by private, industry-driven management initiatives. A specific case study is considered: the International Seafood Sustainability Foundation (ISSF). Potential lessons are then drawn as to how such private initiatives might be used to supplement, if not replace, international management regimes.

The third chapter in this part is by Trevor Daya-Winterbottom: 'Black Coral Forests and Marine Biodiversity'. The author explains that most, if not all, countries are struggling to halt the decline of indigenous biodiversity, and New Zealand is one such. One problem is that, notwithstanding baseline state of the environment reporting since 1997, there has been political resistance to preparing national policy statements regarding indigenous biodiversity to assist with interpreting the law, and attempts to implement modern, up-to-date legislation have stalled since 2002. This chapter focuses on a certain coastal marine area, and the largest global submarine forest of black coral trees found in that area, as a mechanism for evaluating the effectiveness of New Zealand's marine protection laws. Generally, an empirical approach is used to interrogate what environmental practice would look like if carried out in a sustainable way, what government entities and the private sector are doing to foster sustainable outcomes, and what should be done to promote sustainability. The overall argument made in the chapter is that different evaluation approaches (constitutional, empirical and governance) are useful in exposing any gaps between policy and practice within the legal system.

The final chapter in this part, and in the book, is by Carina Costa de Oliveira and Sandrine Maljean-Dubois: 'The Contribution that the Concept of Global Public Goods Can Make to the Conservation of Marine Resources'. 'Global public goods', 'common heritage' and the 'global commons' are concepts used to describe elements of the political and legal regime concerning marine resources. In this chapter it is explained, however, that these concepts are limited when it comes to determining the obligations of states and of international organizations regarding marine resources conservation. It is then averred that - even if 
their intrinsic purpose can be questioned - these concepts currently dominate the debate on marine resources. Their existence, whether scientifically useful or not, can therefore not be denied or ignored. It is argued that, to understand what they can concretely offer to the legal discussions on marine resources, these concepts must be articulated with more precise legal obligations such as the 'obligation to cooperate' and the 'duty of due diligence', as applied to marine resources. Accordingly, this chapter investigates how these concepts can be combined and related to more concrete obligations in order to be made more effective.

This chapter might potentially have been placed in the first part as it does take a broad, global approach. On the other hand, it deals with marine resources and its global scope makes it a useful 'concluding' chapter to the book.

\section{CONCLUSIONS}

A number of matters are striking about the protection of biological diversity in forest and marine areas. One is that neither area is well comprehended - in many ways, we are only scratching the surface of understanding the true value of the ecosystem goods and services they provide; and we have precious little understanding of what is needed to keep them, and the myriad inter-relationships between species within them, healthy.

Not only do they share these features of complexity and of poor human understanding of their relevance and needs, but they share also the unfortunate distinction of being under serious threat. Another common feature is that both fall within national boundaries and outside of them significant areas of the oceans fall within state boundaries, but these are affected by what happens in areas beyond national jurisdiction; and while most forests are under the control of national authorities, many are parts of much larger transboundary wholes, and are affected by what happens internationally. They share also the feature that, apart from a few localized success stories, far too little is being done to protect them - and urgent protection is needed, both within national legal systems and within international legal regimes. Indeed, it is obvious today that effective enforcement of both national and international legal instruments is required if there is to be any improvement in their states of health.

An interesting, and often overlooked, feature of a combined study of marine and forest biodiversity is that the international legal regimes which govern them can be seen as starkly different. Although concern, both national and international, for the protection of forests probably began many hundreds of years before similar concern for the oceans began, it 
is the oceans which today appear, if anything, to be over-regulated while international instruments for the protection of forests are by comparison virtually non-existent. Paradoxically, our view is that this makes the study of the two areas more, not less, valuable. If similar problems are appearing in, and biological diversity similarly declining in, both an area that is heavily regulated and an area that is virtually not regulated, then perhaps a new approach with new solutions is needed. It is the hope of the editors that readers of this book will consider carefully both the commonalities and the differences between the regimes that seek to protect forest and marine biodiversity - and then will give thought to these similarities and divergences, and to the lessons that can be learned for the future.

A useful place to apply such lessons would be in the current negotiations, under the auspices of UNCLOS, towards a new international instrument on the protection of biodiversity in areas beyond national jurisdiction - essentially meaning on the high seas. Unfortunately, there is not currently any similar move towards a global instrument which would recognize the importance of, and provide some protection to, biodiversity in forests. While an obvious difference between the two lies in the fact that all forests lie within national sovereignty, a true understanding of the nature of biodiversity would recognize that as much as it is impossible to separate the protection of the high seas from protection of ocean waters within national sovereignty, so it is artificial not to see connections between the marine and the forest environments - both in practice and in law. That some ocean waters and all forests lie within national sovereign areas does not alter their importance to biodiversity on the whole planet. 